\title{
ARSITEKTUR TRADISIONAL RUMAH BETAWI
}

\author{
Oleh Suwardi Alamsyah P. \\ Balai Pelestarian Sejarah dan Nilai Tradisional Bandung \\ Jln. Cinambo No. 136 Ujungberung Bandung \\ Email: bpsntbandung@ymail.com
}

\begin{abstract}
Abstrak
Arsitektur tradisional rumah Betawi dalam tulisan ini difokuskan pada arsitektur tradisional rumah tinggal, yakni rumah Gudang, rumah Joglo, dan rumah Bapang/Kebaya. Rumah-rumah tersebut masih dapat disaksikan di perkampungan masyarakat Betawi di daerah Condet Kelurahan Balekambang, Jakarta Timur. Bentukbentuk rumah tersebut menunjukkan bahwa masyarakat Betawi terbuka terhadap pengaruh luar. Hal tersebut dapat dilihat dan dipelajari dari pola tapak, pola tata ruang dalam, dan terutama dari sistem struktur dan bentuk serta detail dan ragam hias rumah.
\end{abstract}

Kata Kunci: Arsitektur tradisional, rumah.

\begin{abstract}
Traditional Architecture forms house of Betawi in this article load traditional architecture of house remain, namely Warehouse house, house of Joglo, and house of Bapang / kebaya, what still see and can be witnessed is countrified society of Betawi in area of Condet Sub-District Of Balekambang, Jakarta East. The Forms House indicate that society of Betawi much more open from external influence. The mentioned can be seen and studied from tread pattern, planology pattern in, and especially from structure system and form and also decorative manner and detail which owned it.
\end{abstract}

Keywords: traditional architecture, building.

\section{A. Pendahuluan}

Salah satu unsur di antara identitas pendukung kebudayaan adalah arsitektur tradisional yang tumbuh dan berkembang bersamaan dengan pertumbuhan suku bangsa atau etnik yang bersangkutan. Dalam arsitektur tradisional terkandung secara terpadu wujud ideal, wujud sosial dan wujud material suatu kebudayaan.

Di beberapa tempat, arsitektur tradisional tinggalan masa lalu yang masih diwariskan cara menciptakannya dan diteruskan pembangunannya oleh masyarakat, merupakan bentuk "peninggalan" dari suatu kebudayaan yang sekaligus berasal dari suatu masyarakat yang relatif homogen. Oleh karena itu, secara fisik (dan juga non-fisik seperti segi suasana dan simboliknya), arsitektur tradisional ini muncul dan membentuk suatu rona (setting) menurut suatu pola dan keteraturan tertentu yang jarang ada pada suatu lingkungan masyarakat yang heterogen dan kompleks.

Kepentingan untuk melestarikan gaya arsitektur itu memang terasa sekali, bukan saja karena alasan-alasan di atas, tetapi juga banyak pihak berpendapat bahwa arsitektur tradisional rumah 
Betawi, sekarang cenderung kepunahan karena beberapa sebab.

Pertama, kota Jakarta adalah kota metropolitan yang berkembang cepat. Seiring dengan itu segala aspek kehidupan modern ikut melanda Jakarta, termasuk arsitektur modernnya. Tidak seperti dengan arsitektur lainnya yang agak terisolasi dari perkembangan kehidupan modern yang cepat karena terdapat di pedesaan, arsitektur tradisional Betawi terdapat tepat di kota Metropolitan Jakarta, sehingga perkembangan Jakarta itu juga melanda daerah-daerah di mana terdapat peninggalan arsitektur tradisional Betawi. Karenanya secara fisik terjadi desakan terhadap daerah-daerah yang terdapat rumah-rumah dengan arsitektur Betawi dalam bentuk pembangunan kawasan perumahan baru, prasarana dan sarana kota yang baru. Di samping, adanya perubahan-perubahan kebutuhan masyarakat setempat menyebabkan terjadinya perubahan fisik terhadap rumah-rumah Betawi secara langsung.

Kedua, ada dugaan, bahwa pengetahuan mengenai tata bangunan tradisional Betawi, terutama yang mencakup upacara dalam pembuatannya serta jenis ragam hiasnya, telah terputus kesinambungannya sehingga generasi muda Betawi pada masa kini sudah tidak mengenal seluk beluk mengenai seni bangunan tradisional tersebut. Hal ini juga nampaknya berhubungan dengan kenyataan bahwa "arsitek" yang merancang dan membangun rumah atau bangunan arsitektur Betawi sudah tidak ada. Kalaupun ada, hanya beberapa orang yang tinggal dan sudah uzur sehingga sudah sulit untuk mengkomunikasikan gagasan dan atau idenya.

Dengan demikian, usaha untuk mempertahankan keberadaan arsitektur tradisional rumah Betawi adalah penting sebagai bagian dari usaha menyelamatkan kebudayaan nasional pada umumnya dan kebudayaan daerah pada khususnya, dalam hal ini adalah seni bangunan tradisional rumah Betawi.

Selanjutnya, penulisan ini adalah untuk mendokumentasikan dan mendeskripsikan aspek dan unsur arsitektur tradisional rumah Betawi yang meliputi lingkungan, tapak, tata ruang dalam, struktur dan bentuk, detail dan ragam hias, serta cara mendirikannya; mendeskripsikan mengenai keberadaan arsitektur tradisional rumah Betawi serta berbagai faktor yang mempengaruhinya; menjadikan bahan pertimbangan pihakpihak yang berkepentingan untuk membuat kebijakan yang berkenaan dengan masalah permukiman penduduk, serta dapat dijadikan bahan informasi dalam rangka pengenalan dan pelestarian sumber budaya.

Ruang lingkup penulisan ini adalah arsitektur tradisional rumah Betawi, meliputi lingkungan, tapak, ruang dalam, struktur dan bentuk, detail dan ragam hias, dan cara mendirikan rumah. Masing-masing diuraikan mengenai kemungkinan-kemungkinan latar belakang keberadaannya maupun faktor-faktor yang mempengaruhinya, di samping tradisi atau pola berfikir yang berlaku serta kaitannya antara penghuni dengan rumah menurut lingkup budaya.

Metode penelitian yang digunakan adalah metode deskriptif dengan metode atau penelaahan data bersifat kualitatif, yakni suatu cara yang digunakan untuk menyelidiki dan memecahkan masalah yang tidak terbatas pada pengumpulan data, melainkan meliputi analisis dan interpretasi sampai kepada kesimpulan yang didasarkan atas penelitian tersebut (Surakhmad, 1985:139).

\section{B. Hasil dan Bahasan}

Arsitektur adalah salah satu bentuk hasil kebudayaan suatu masyarakat. Ia sekaligus juga dapat memberikan gambaran mengenai hasil-hasil kebudayaan 
lainnya seperti teknologi, kesenian dan lain sebagainya. Arsitektur tidak terlepas dari keadaan masyarakat yang menciptakannya maupun keadaan lingkungan yang mempengaruhinya.

Dibandingkan dengan arsitektur rumah tradisional lainnya di Pulau Jawa dan daerah-daerah lain di Indonesia, arsitektur tradisional rumah Betawi jauh lebih terbuka di dalam menerima pengaruh dari luar. Hal ini dapat dilihat dan dipelajari dari pola tapak, pola tata ruang dalam, dan terutama dari sistem struktur dan bentuk serta detail dan ragam hias yang dimilikinya. Hal ini juga menggambarkan keterbukaan masyarakat pencipta dan pemilik arsitektur rumah Betawi ini terhadap pengaruh unsurunsur kebudayaan lainnya.

\section{Tata Letak Rumah dan Lingkungannya}

Pola perkampungan atau permukiman di daerah Condet Kelurahan Balekambang dan permukiman asli lainnya di wilayah Jakarta Timur, tata letaknya dibedakan berdasarkan kelompok rumah-rumah yang berdiri di bagian dalam, yakni agak jauh dari jalan besar dan yang berdiri di bagian luar biasanya dekat atau langsung berhadapan dengan jalan.

Permukiman pada bagian dalam memiliki pola yang terpencar karena rumah-rumah yang ada dibangun di tengah-tengah kebun buah-buahan atau bidang-bidang lahan yang kering. Sedangkan pada permukiman di bagian luar, rumah-rumah lebih bersifat mengelompok padat atau berjejer di sepanjang jalan atau gang dan hanya dikelilingi oleh pekarangan-pekarangan sempit. Namun hal tersebut, tidak berarti pemilik rumah memiliki lahan yang sempit di desa bersangkutan. Karena seringkali kebun buah-buahan atau lahan kering yang dimilikinya ada di lokasi lain di desa bersangkutan, sehingga rumah- rumah di kampung bagian luar terpisah dari kebun buah-buahannya.

Permukiman di bagian dalam atau daerah hinterland seperti Condet Kelurahan Balekambang, pola yang terpencar seperti tersebut di atas disebabkan karena pada umumnya penduduk asli secara perseorangan memiliki lahan darat yang luas dan masing-masing rumah mereka berdiri di atas lahan yang mereka miliki.

Walaupun pada perkampungan tradisional Betawi di daerah hinterland kepemilikan lahan telah bersifat perseorangan, pembatas kepemilikan lahan cukup dengan menanam sejenis pohon seperti jaran, petai cina, jarak, secang, dan sebagainya. Khusus mengenai pepohonan pembatas kebun, dipilih yang mudah tumbuh dan awet, akan tetapi bukan jenis pohon yang menghasilkan buah-buahan yang bisa dimakan. Hal ini dimungkinkan untuk menghindari terjadinya sengketa mengenai buah-buahan dengan tetangga pemilik kebun di sebelahnya. Seperti juga dengan lahan kebun, halaman rumah tidak dibatasi dengan pagar. Untuk menciptakan privacy, sebagai pengganti pagar halaman pada bagian depan rumahrumah tradisional Betawi biasanya dibuat langkan, yaitu pagar yang disebut jaro, terbuat dari bahan bambu atau kayu, sehingga pandangan dari luar rumah tidak tembus ke dalam rumah.

Batas mengenai kepemilikan lahan maupun halaman rumah dari permukiman tradisional Betawi kurang lebih sama dengan kebanyakan permukiman atau perkampungan tradisional lainnya di Indonesia. Kesamaannya adalah tidak terlihat adanyanya tanda-tanda fisik yang jelas atau permanen, walaupun pada perkampungan Betawi seringkali tanda tersebut ada, sementara pada perkampungan tradisional lainnya tidak ada. Namun dari segi pola tata letak 
rumah pada permukiman tradisional Betawi sama sekali berbeda dengan pola tata letak pada permukiman tradisional yang lain.

Rumah-rumah pada permukiman tradisional Betawi dapat dikatakan tidak memiliki arah mata angin maupun orientasi tertentu, seperti halnya pada rumah-rumah tradisional Baduy di Kanekes Kabupaten Lebak Banten ataupun Kampung Naga di Salawu Kabupaten Tasikmalaya dan kampungkampung lain di Indonesia. Artinya tidak ada suatu keharusan atau kepercayaan tertentu yang harus diikuti dalam menetapkan arah hadap suatu rumah. Selain itu tidak ada bangunan atau ruang tertentu yang menjadi pusat dari perkampungan, yang berfungsi menentukan orientasi dari rumah-rumah yang ada. Semisal pada permukiman suku Baduy di Desa Kanekes Banten, rumah-rumah berorientasi pada rumah Puun yang menjadi pusat perkampungan. Dengan demikian, di samping adanya arah hadap yang diikuti, terdapat pula suatu bagian dari perkampungan yang menjadi suatu struktur atau bangunan serta suatu ruang yang lebih penting dari yang lainnya dan berfungsi sebagai pusat terhadap rumahrumah penduduk. Hal ini tidak terdapat pada permukiman tradisional Betawi. Pada permukiman Betawi Condet, orientasi atau arah hadap rumah lebih ditentukan oleh alasan-alasan praktis seperti bentuk dan orientasi pekarangan. Dengan kata lain kemudahan mencapai jalan. Kemudian pada bagian pekarangan, arah mata angin dan orientasi dari bagian-bagian tata letak pun tidak begitu jelas. Demikian pula fungsi-fungsi yang berada di atas pekarangan sangat bergantung pada kebutuhan dari pemilik lahan atau pemilik rumah yang bersangkutan.

Tata letak rumah atau tapak rumah dibangun di atas lahan yang terpisah dari letak kebun. Namun demikian, di bagian pekarangan rumah pun mereka tanami dengan tanaman buah-buahan. Di atas lahan rumah dimungkinkan berdiri beberapa rumah tinggal karena adanya pewarisan atau jual beli atas sebagian dari bidang lahan pemilik semula, yang kemudian di atasnya dibangun rumah baru oleh pemilik baru. Namun demikian, di perkampungan tradisional Betawi di daerah hinterland, terdapat suatu kebiasaan kalau ada anak seorang pemilik bangunan atau lahan telah menikah dan belum mampu membuat rumah, maka si orang tua akan memberikan bagian dari rumahnya semisal paseban atau dapur dengan cara membongkarnya dan memindahkannya ke tempat lain. Cara-cara seperti ini menyebabkan terjadinya proses fragmentasi dan pemadatan pemilikan lahan pada permukiman atau perkampungan tradisional Betawi.

Kemudian di atas lahan yang sama, selain dimungkinkan berdirinya beberapa rumah, dapat pula berdiri fungsi-fungsi lain selain rumah seperti kuburan, lapangan badminton dan sebagainya. Selain itu kamar mandi, sumur atau WC biasanya ditempatkan di belakang rumah sebelah kiri atau kanan dan itupun tidak merupakan ketentuan. Dahulu membuat WC, sumur cukup dengan mengali tanah di kebun kemudian ditutup dengan papan kayu aren dan dilubangi, yang disebut jamban, cubluk dan atau jamban cemplung. Di Condet, pada waktu Sungai Ciliwung masih bersih airnya, mandi dan mencuci cukup di sungai. Kebiasaankebiasaan tersebut nampaknya yang membentuk tata letak kamar mandi atau WC di luar rumah seperti yang ada sekarang.

Baik pada perkampungan yang tata letaknya bersifat memencar maupun yang bersifat mengelompok pada permukiman tradisional Betawi, pola tata letak 
perkampungan pada hakekatnya tumbuh karena perkembangan individual dari rumah-rumahnya. Tidak adanya suatu keharusan arah hadap maupun orientasi bersama dari rumah-rumah pada permukiman tradisional Betawi pada hakekatnya karena adanya perkembangan individual tersebut. Pada permukiman masyarakat Betawi, khususnya di Condet Kelurahan Balekambang tidak ada norma adat yang berlaku dalam mengatur perkembangan rumah atau pola perkampungan; namun yang ada hanyalah kebiasaan dan nampaknya berkaitan dengan alasan-alasan praktis dan penguasaan teknologi yang dimilikinya. Berkaitan dengan tidak adanya suatu norma adat, dan adanya pengaruh kehidupan perkotaan, dalam hal ini adalah kehidupan perkotaan Jakarta sepanjang perjalanan sejarahnya.

\section{Persiapan dan Penggunaan Bahan \\ Bangunan}

Musyawarah merupakan suatu cara yang sangat penting untuk pengambilan keputusan mengenai pendirian suatu rumah di Betawi dahulu. Musyawarah pada saat itu dimaksudkan untuk membicarakan pembangunan dan jenis rumah tinggal yang akan dibangun, apakah jenis rumah Gudang, Joglo, atau Bapang. Biasanya dalam musyawarah itu berisi permohonan kepada keluarga untuk bisa membantu meringankan biaya. Di samping itu, dapat diketahui apa saja yang sudah ada dan apa saja yang harus dipersiapkan, selain sudah tersedianya lahan yang di atasnya akan didirikan bangunan. Dahulu pertemuan semacam itu disebut andilan, yakni di antara mereka dalam hal ini keluarga akan menyanggupi membantu sesuai dengan kemampuannya. Mungkin ada yang memberikan pohon yang ada di kebunnya yang akan dijadikan bahan bangunan, baik tiang atau papan serta keperluan lainnya. Dahulu, mendirikan rumah tidak perlu mendapatkan izin dari pemerintah, asal rumah tersebut dibuat di tanahnya sendiri. Namun demikian pertimbangan/ persetujuan anggota keluarga sangat menentukan dalam membangun rumah, baru kemudian seseorang dapat melaksanakan niatnya untuk mendirikan rumahnya.

Berikut ini adalah beberapa kegiatan yang penting yang dilakukan masyarakat Betawi di dalam mendirikan rumah. Sebagian dari kegiatan-kegiatan ini biasanya memerlukan persetujuan keluarga. Pada saat ini, kegiatan-kegiatan beserta upacara-upacara dan pantanganpantangan yang ada, masih dijalankan oleh sebagian masyarakat Betawi di dalam mendirikan rumah.

Seperti juga pada proses membangun suatu bangunan, dalam membangun rumah Betawi dikenal ada beberapa tahapan. Dimulai dari saat membangun sampai sesudah membangun. Kegiatan yang dilakukan meliputi upacara-upacara dan kegiatan fisik membangun. Selain itu, dalam membangun rumah tinggal di Betawi pada saat itu dikenal pula adanya kepercayaan maupun pantangan tertentu, walaupun sifatnya tidak ketat, karena kepercayaan masyarakat Betawi terhadap Islam yang kuat. Semisal, setelah ditentukan hari awal membangun, maka yang akan membangun rumah mengundang tetangga untuk merowahan (tahlilan). Kegiatan tadi sebagai ungkapan permohonan kepada Yang Mahakuasa agar dalam membangun rumah mendapat kelancaran dan kebaikan. Pada saat merowahan yang akan membangun rumah memohon kepada tetangga untuk rela hati membantu, bergotong royong menebang pohon dan meratakan tanah yang akan dibangun rumah. Orang Betawi menyebut kegiatan ini dengan nyambat atau sambatan. Pada hari yang 
sudah ditentukan, maka lahan tanah yang di atasnya akan dibangun rumah diratakan atau istilah Betawi disebut membuat batur atau baturan. Sementara itu ahli bangunan yang disebut tukang sudah memulai membuat tiang guru, pondasi, rorag, kuda-kuda, pengeret, penglari, papan nok, kaso, ander, siku, ragam hias dan lain sebagainya.

Pengadaan bahan bangunan sangat dipengaruhi oleh lingkungan di mana masyarakat itu berada. Bagi penduduk Betawi di Condet yang hidup bercocok tanam terutama buah-buahan, bahan bangunan yang dipergunakan untuk rumah mereka biasanya terdiri atas kayu pohon buah-buahan yang sudah tua dan tidak produktif lagi, semisal kayu nangka, kayu duren, kayu kecapi, kayu juwet atau jamblang, kayu cempaka, kayu jengkol, dan lain-lainnya.

Kayu nangka dan kayu juwet mempunyai ketahanan yang baik. Di daerah Condet ditemukan jenis kayu tersebut yang sudah membatu. Oleh karena itu, kayu nangka merupakan jenis kayu yang sering dipilih untuk dibuat sebagai tiang utama bangunan atau tiang guru, dinding papan rumah, serta sebagai pintu panel berukir. Selain itu, kayu nangka dan kayu juwet akan jauh lebih indah jika diambil bagian tengahnya, karena memiliki warna kuning yang bagus. Kayu cempaka sebaiknya dipakai untuk kusen pintu bagian atas, karena ada anggapan bahwa kayu cempaka memiliki makna tertentu yaitu agar pemilik rumah senantiasa dihormati dan disenangi tetangga. Di sisi lain, kayu asem bagi masyarakat Betawi pantang untuk dijadikan bahan bangunan, karena menurut anggapan mereka sifat asem dari kayu tersebut akan mempengaruhi harmonisasi antara pemilik rumah dengan tetangga, juga memperlihatkan kesan kumal, gersang dan tidak berwibawa.
Proses penggarapan atau pengerjaan kayu tersebut dilakukan setelah pohon yang terpilih ditebang dan diproses sesuai dengan kebutuhan. Kayu tersebut kemudian dikeringkan dengan jalan ditumpuk di halaman atau di paseban dalam bentuk gelondongan atau hasil potongan. Untuk jenis kayu yang kurang daya tahannya biasanya diawetkan dengan cara direndam dalam kolam secepat-cepatnya satu bulan. Proses perendaman yang lebih lama akan lebih baik kualitasnya.

\section{Struktur dan Bentuk}

Seperti telah disinggung di muka, bentuk rumah Betawi dapat dilihat berdasarkan bentuk dan struktur atapnya. Oleh karena itu, rumah tradisional Betawi mengenal 3 (tiga) bentuk utama; yaitu rumah Gudang, rumah Joglo, dan rumah Bapang atau Kebaya; yang ternyata berkaitan dengan bentuk dan pembagian denahnya.

\section{a. Rumah Gudang}

Rumah Gudang memiliki tengah segi empat, memanjang dari depan ke belakang. Atapnya berbentuk pelana, tetapi terdapat pula rumah gudang yang beratap perisai. Struktur atap rumah gudang, baik yang beratap pelana maupun perisai, tersusun dari kerangka kuda-kuda dan ditambah satu elemen struktur atap, yaitu jure.

Struktur kuda-kuda yang terdapat pada rumah gudang pada umumnya bersistem agak kompleks karena sudah mulai terdapatnya batang tekan miring (dua buah) yang saling bertemu pada sebuah batang tarik tegak yang pada rumah Betawi lazim disebut ander. Sistem seperti ini tidak dikenal pada rumah-rumah tradisional lainnya di Indonesia. Sehingga dapat dipastikan, bangunan-bangunan yang dibangun Belanda di Jakarta dahulu telah 
memperkenalkan sistem tersebut pada penduduk setempat, yang kemudian menerapkannya pada apa yang kemudian dikenal sebagai rumah gudang. Selain itu, pada bagian depan rumah gudang terdapat sepenggal atap miring yang disebut juga topi atau dak atau markis, yang berfungsi menahan cahaya matahari atau tempias hujan pada ruang depan yang selalu terbuka.

\section{b. Rumah Joglo}

Nama dan bentuk rumah joglo ini dapat dipastikan hasil pengaruh langsung dari arsitektur atau kebudayaan Jawa pada arsitektur rumah Betawi. Namun tidak seperti pada rumah joglo yang terdapat di Jawa Tengah, integrasi antara denah, tiang-tiang penopang struktur atap dan struktur atapnya sendiri pada rumah joglo Betawi tidak begitu nyata seperti pada rumah joglo di Jawa Tengah, tiangtiang utama penopang struktur atap adalah unsur utama yang mengarahkan pembagian ruang pada denah; sedangkan pada rumah joglo Betawi, hal ini tidak nyata. Selain itu, pada rumah joglo asli di Jawa Tengah, struktur bagian joglo dari atap disusun oleh sistem struktur temu gelang atau payung; sedangkan pada rumah joglo Betawi disusun oleh kudakuda. Namun berbeda dengan rumah gudang, sistem kuda-kuda pada rumah joglo Betawi adalah kuda-kuda timur yang tidak mengenal batang-batang diagonal seperti yang terdapat pada sistem kuda-kuda barat yang diperkenalkan oleh Belanda.

Pada umumnya, rumah joglo Betawi memiliki bentuk denah bujur sangkar. Tetapi perlu dicatat, dari seluruh bentuk bujur sangkar itu, bagian yang sebenarnya membentuk rumah joglo adalah suatu bagian empat persegi panjang yang salah satu garis panjangnya terdapat dari kiri ke kanan ruang depan. Dengan demikian sepenggal bagian depan dari ruang depan sebenarnya diatasi oleh terusan (Sunda: sorondoy) dari atap joglo yang ada. Sehingga bagian ruang depan yang diatapi sorondoy dan bagian utama rumah yang diatapi joglo secara keseluruhan menghasilkan denah berbentuk bujur sangkar.

\section{c. Rumah Bapang/Kebaya}

Pada prinsipnya, atap rumah bapang atau kebaya adalah juga berbentuk pelana. Tetapi berbeda dengan atap rumah gudang, bentuk pelana rumah bapang adalah tidak penuh. Kedua sisi luar dari atap rumah bapang sebenarnya dibentuk oleh terusan (Sunda: sorondoy) dari atap pelana tadi yang terletak di bagian tengahnya. Dengan demikian, maka yang berstruktur kuda-kuda adalah bagian atap pelana yang berada di tengah. Dalam hal ini, sistem struktur atap yang dipakai adalah sistem kuda-kuda timur.

Walaupun secara garis besar struktur dan bentuk rumah tradisional Betawi dapat dibagi menurut ketiga jenis rumah tinggal seperti diuraikan di atas, secara keseluruhan rumah Betawi adalah bersruktur rangka kayu, walaupun pada beberapa tempat bambu pun digunakan untuk bahan struktur bangunan rumah tinggal, di seluruh wilayah penamaan dari komponen struktur adalah sama, dan pada umumnya rumah Betawi adalah rumah yang beralaskan tanah yang diberi lantai tegel atau semen yang juga disebut rumah depok.

Struktur rumah Betawi pada hakekatnya adalah struktur standar dan karenanya sangat bersifat fungsional. Kemudian pada struktur atap, unsur struktur yang bervariasi disebabkan oleh pengaruh dari arsitektur luar yang bermacam-macam, semisal sekor untuk penahan dak atau markis dan struktur overstek atau penanggap. Untuk sekor penahan dak, selain yang terbuat dari kayu, terdapat pula yang terbuat dari 
logam yang menunjukkan pengaruh Eropa dan Belanda. Begitu juga untuk siku penanggap, selain kedua variasi dilihat dari pengunaan bahannya, diketahui juga adanya pengaruh Cina karena terdapatnya konstruksi Tou-Kung pada banyak rumah Betawi.

\section{Gambar 1}

Bentuk-Bentuk Siku Penanggap
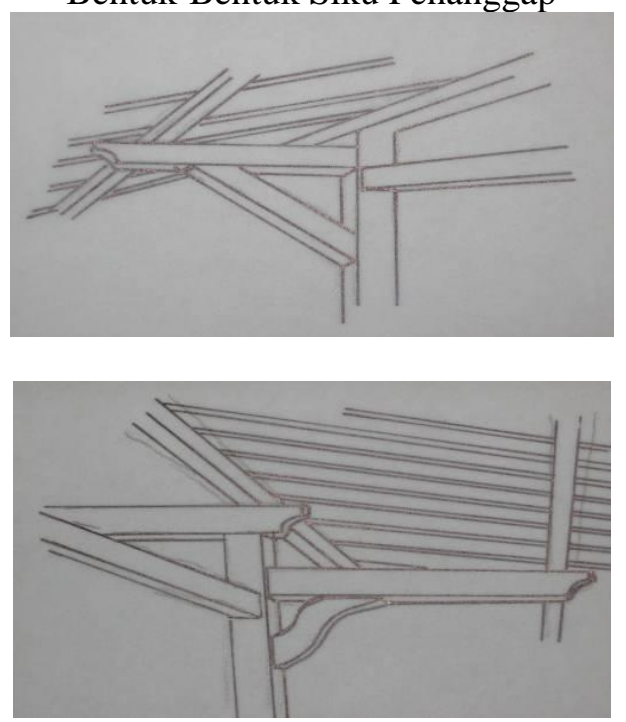

Sumber: BPSNT Bandung 2009

Pada rumah Betawi yang beralaskan tanah di daerah Condet, pengaruh Belanda dapat dilihat dari penggunaan rorag yang terbuat dari bata sebagai penghubung antara struktur tegak, baik berupa dinding setengah tembok (Sunda: duduk jandela) atau dinding kayu atau bambu dengan lantai. Pada rumah-rumah di Jawa Tengah atau Jawa Timur yang juga beralaskan tanah, rorag tidak dikenal kecuali pada keraton atau rumah bangsawan yang notabene sudah terkena pengaruh unsur-unsur arsitektur Belanda.

Penggunaan alas untuk lantai rumah panggung adalah papan yang dilapisi anyaman kulit bambu. Pada rumah bukan panggung, pada mulanya adalah lantai itu sendiri. Sedangkan untuk rumah orang kaya setempat dipergunakan ubin tembikar sebagai pelapis lantai tanah. Pada perkembangan selanjutnya, dipergunakan ubin semen. Penggunaan bahan ubin tembikar atau ubin semen nampaknya dipengaruhi oleh arsitektur bangunan Belanda atau Eropa.

Dari paparan di atas dapat disimpulkan, bahwa baik sistem struktur, bentuk, maupun penggunaan bahan rumah tradisional Betawi sangat terbuka di dalam menerima pengaruh dari luar. Pengaruh-pengaruh arsitektur Sunda, Jawa, Belanda dan Cina telah membentuk arsitektur rumah Betawi seperti yang bisa dilihat sekarang. Pengaruh tersebut telah berjalan secara sendiri-sendiri atau secara bersama-sama. Jika detail dan ragam hias dari rumahrumah Betawipun dipelajari, ternyata pengaruh Arab juga telah ikut berperan di dalam pembentukan arsitektur rumah Betawi. Secara prinsip, bentuk struktur dan konstruksi rumah Betawi tidak memiliki makna filosofis khusus. Semua elemen muncul karena alasan fungsional.

Kemudian kaso dan reng diletakkan di atas kuda-kuda sebagai tempat meletakkan atap (genteng). Pada sekor atau penyangga atap selain berfungsi struktural, terdapat juga fungsi estetis, seperti halnya konstruksi sekor yang berbentuk sekor pengaruh arsitektur Cina yang disebut Tou-kung.

\section{Ragam Hias}

Ragam hias mungkin merupakan salah satu ungkapan arsitektur yang paling penting yang terdapat pada arsitektur rumah tinggal Betawi. Pentingnya untuk diperhatikan ragam hias di dalam arsitektur Betawi ini bukan saja karena penggunaannya yang terdapat pada hampir sebagian besar unsur bangunan rumah tinggal, tetapi juga karena keberadaannya jelas menunjukkan adanya pengaruh dari berbagai 
kebudayaan yang pernah berhubungan dengan Betawi.

Pada rumah Betawi dapat diperhatikan bahwa unsur-unsur dan hubungan struktur-struktur atau konstruksi seperti sekor, siku penanggap, tiang, atau hubungan antara tiang dengan batu kosta, sering dijumpai memiliki detail atau mendapat sentuhan dekoratip.

\section{Gambar 2}

Konstruksi Penyokong Overhang

'Tou-Kung' dan Dekoratif Skor dan Lispank
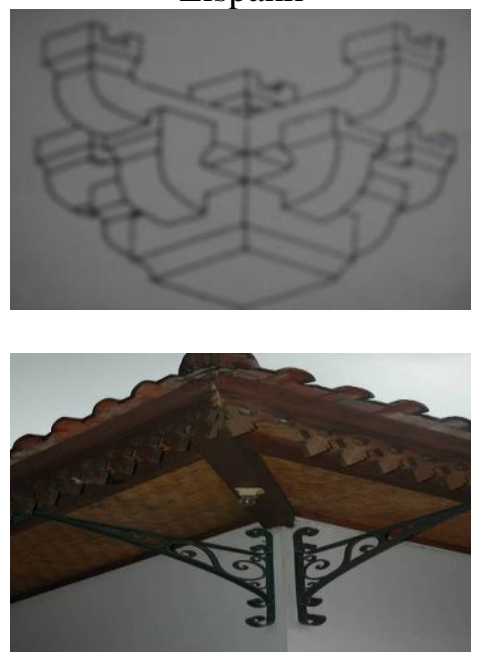

Sumber: Dinas Kebudayaan DKI Jakarta 1991 dan BPSNT Bandung 2009

Konstruksi Tou-kung yang diadaptasi dari arsitektur Cina untuk siku penanggap seperti yang telah dikemukakan di muka, bukan saja merupakan suatu prinsip konstruksi tetapi juga merupakan suatu sentuhan dekorasi. Tiang-tiang bangunan jarang dibiarkan berbentuk polos bujursangkar menurut irisannya, tetapi diberikan sentuhan akhir pada sudutnya; demikian pula detail-detail ujung bawah yang berhubungan dengan batu kosta (Sunda: tatapakan) maupun bagian ujung atas yang berhubungan dengan penglari dan pangeret dari tiang, selalu diberi penyelesaian detail yang selain berfungsi secara struktural juga bersifat dekoratip.

Contoh lainnya adalah pada sekor besi cor, yang merupakan hal yang diperkenalkan oleh arsitektur Belanda dan Eropa dilihat dari segi penggunaan bahannya, bentuknya tidak semata-mata fungsional tetapi juga dekoratip. Dalam hal ini bentuk dekoratip sekor besi cenderung mengadaptasi bentuk-bentuk yang juga berkembang di Eropa (artdeco, art nouveau, dan lain sebagainya).

Penggunaan gaya arsitektural dengan ragam hias yang lebih banyak lagi terdapat pada unsur-unsur bangunan yang bersifat non-struktural seperti pada lijstplank, pintu, langkan (langgar pada rumah), jendela, garde (bentuk relung yang menghubungkan ruang depan dengan ruang tengah), sisir gantung (bidang terbuat dari papan yang menggantung di bagian depan rumah), dan lain sebagainya. Pada unsur-unsur ini ragam hias diterapkan begitu teliti sehingga pengerjaannya lebih merupakan suatu keahlian tersendiri dari keahlian mendirikan bangunan. Selain itu jenis ragam hias yang dipergunakan pada unsur-unsur non-struktural ini jauh lebih bervariasi, yang antara lain menunjukkan banyaknya pengaruh luar yang berbekas pada penciptaannya.

Khusus mengenai garde yang berfungsi sebagai penghubung di ruang tengah dan sisir gantung yang menggantung di ruang depan, keberadaan dan pemasangannya bersifat berdiri sendiri, sehingga dapat disebut sebagai elemen estetis yang utuh. Kenyataan ini juga menunjukkan bahwa pembuatan kedua unsur ini bersifat tersendiri dari pendirian bangunan, dan diperlukan keahlian khusus untuk membuatnya.

Berdasarkan pola visual yang ditampilkannya, jenis-jenis ragam hias yang seringkali ditemukan pada rumah 
Betawi memiliki nama-nama: Pucuk Rebung, Cempaka, Swastika, Matahari, Kipas, Jambu Meda, Delima, Flora, dan Gigi Balang serta lukisan kaca bergambar Buraq. Dari pola ragam hias ini serta cara menggunakannya dapat pula disimpulkan adanya pengaruh Cina, Arab, maupun Eropa.

Jenis dan ragam hias pada arsitektur tradisional rumah Betawi tersebut, selain sebagai variasi juga memiliki makna-makna tertentu, baik yang berhubungan dengan pendirinya maupun dengan lingkungan dan pengaruh budaya sepanjang perjalanan sejarahnya, antara lain adalah: Lambang matahari sebagai sumber kehidupan, kekuatan, dan kewibawaan bagi si pemiliknya. Selain itu, sering dihubungkan dengan kebudayaan Arab dan kehidupan bernuansa Islami; Ornamen baji sebagai pembawa kesejukan bagi pemiliknya; Bentuk rantai-rantai sebagai lambang kebersamaan; Ukiran bunga-bunga/flora melambangkan keramahtamahan serta kedamaian si pemilik rumah; Ornamen tombak pada pagar langkan melambangkan gunung, puncak, pencapaian yang lebih tinggi, kewibawaan dan kekuatan untuk melindungi rumah; Ornamen gigi balang pada tepi lijsplank (lisplang) sebagai unsur kegagahan dan estetika; Penggunaan simbol yang berlaku umum sering ditemukan juga pada elemen rumah Betawi. Semisal, garuda pada lubang ventilasi pintu depan yang melambangkan kesetiaan dan kebanggaan terhadap negara; dan Ornamen matahari dan binatang pada rumah pesisir banyak dipengaruhi oleh budaya luar, dan biasanya memiliki makna religius yang kental.
Gambar 3

Jenis-Jenis Ragam Hias

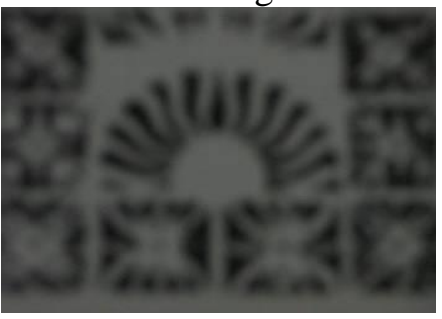

Ragam Hias Matahari

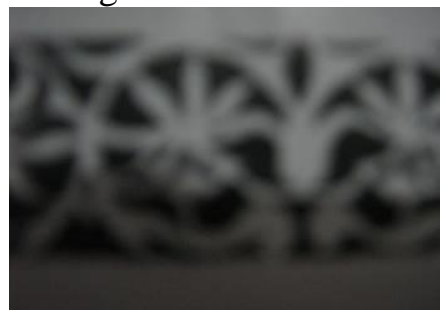

Ragam Hias Flora

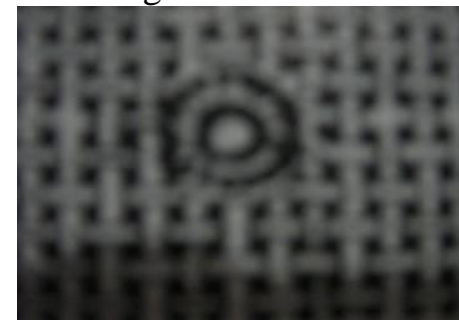

Ragam Hias Baji

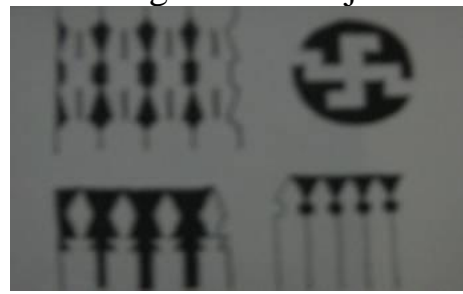

Ragam Hias Tombak

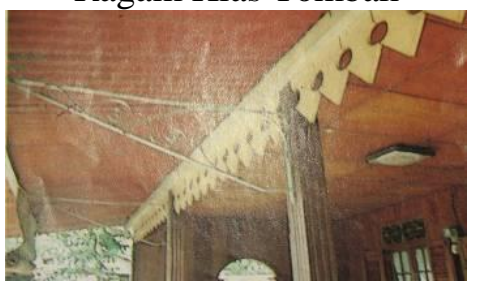

Ragam Hias Gigi Balang 


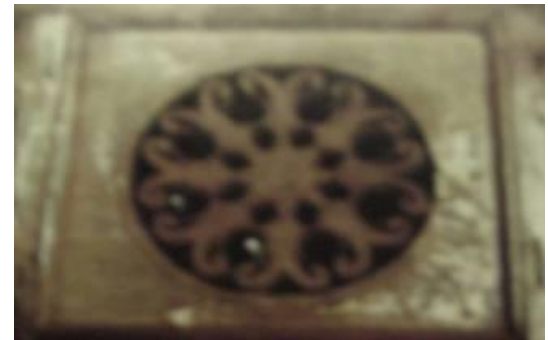

Ragam Hias Matahari

Sumber: Dinas Kebudayaan DKI Jakarta 1991 dan BPSNT 2009

\section{Kebiasaan Mendirikan Rumah}

Setelah menentukan arah bangunan yang akan didirikan dengan memperhitungkan keberadaan "Naga Besar" dan menghitung hari baik, maka dimulaillah pelaksanaan mendirikan bangunan untuk sebuah rumah. Dalam pelaksanaan mendirikan rumah ini, ada beberapa kebiasaan yang dijalankan, termasuk beberapa upacara kecil di dalamnya. Pada umumnya, kebiasaan upacara-upacara ini tidak ada yang langsung berkaitan dengan bangunan rumah itu sendiri, tetapi dijalankan dengan tujuan yang lebih luas, yaitu mendapatkan keselamatan dalam menjalankan kehidupan.

Beberapa kebiasaan yang penting dan banyak dijalankan masyarakat Betawi, terutama pada saat itu di antaranya:

a. Pada saat meratakan tanah untuk tempat bangunan (baturan), di atasnya diletakkan 5 (lima) bata garam, yaitu empat bata garam diletakkan pada keempat pojok tanah di mana rumah akan didirikan dan satu bata diletakkan di tengahtengah. Menurut kepercayaan yang ada, maksud dari peletakan garam tersebut adalah agar tempat bangunan tersebut adalah bebas dari mahluk halus, khususnya selama masa mendirikan rumah. b. Pada waktu pemasangan umpak batu (batu kosta atau pondasi) sebagai alas tiang guru, sebelum tiang guru didirikan, di atas umpak diletakkan uang ringgit, perak atau gobangan. Maksud peletakan uang tersebut adalah agar si pemilik rumah hidup tentram dan rejeki tidak terputus atau selalu punya uang.

c. Pada waktu pemasangan kaso, diadakan selamatan membuat "bubur merah putih", dan kemudian sebagian bubur tersebut ditempatkan dalam daun (diplengsong) yang kemudian diletakkan di ujung atas setiap tiang guru. Maksud kepercayaan tersebut adalah peletakan itu merupakan sesajen untuk "orang atas" atau mahluk halus, agar tidak mengganggu dan tidak menghuni rumah yang dibuat.

d. Pada malam sebelum rumah selesai sepenuhnya, keluarga pemilik rumah tidak diperbolehkan tidur. Hal tersebut dimaksudkan dan dipercaya untuk memberikan keamanan bagi rumah tersebut.

e. Setelah bangunan selesai, yaitu siap untuk dihuni, bagi masyarakat Betawi masih dikenal sejenis upacara atau selamatan rumah dengan menggunakan sesajen. Adapun sesajen yang disediakan untuk selamatan tersebut adalah berupa nasi kuning, nasi putih, macam-macam buah, beserta segala lauk pauk dan kue. Kemudian secara bersama-sama beberapa tetangga dan sanak keluarga terutama yang ikut sambatan berkumpul dengan membaca doa selamat atas keberhasilannya dalam mendirikan rumah tersebut. Kemudian semuanya ini dilaksanakan untuk mendapatkan keselamatan di dalam bertempat tingal dan dalam 


menjalani kehidupan pada
umumnya.

Selain terdapatnya beberapa kebiasaan dan upacara yang berkaitan dengan pendirian suatu bangunan rumah tinggal, terdapat pula kepercayaan mengenai pantangan atau aturan yang harus dipatuhi mengenai bangunan rumah. Tujuan dari adanya pantangan dan aturan ini adalah agar si penghuni rumah mendapatkan keselamatan dari bertempat tinggal di rumah tersebut, dan mendapatkan hal-hal yang baik dalam kehidupannya. Di bawah ini adalah beberapa pantangan dan aturan yang berkaitan dengan penggunaan bahan bangunan.

a. Tidak boleh mendirikan rumah di atas tanah yang dikeramatkan;

b. Tempat rumah untuk anak yang berkeluarga harus berada di sebelah kiri orang tua, karena kalau anak mantu mendirikan rumah di sebelah kanan orang tua bakal "tidak kuat", artinya keluarga anak tersebut akan sakit-sakitan atau susah rejeki.

c. Kayu nangka tidak boleh dibuat trampa atau drompol yaitu bagian bawah kusen pintu (Sunda: bangbarung), sebab ada kepercayaan bahwa orang yang berani melangkahi kayu nangka bisa terkena penyakit kuning.

d. Kayu cempaka dibuat untuk kusen pintu bagian atas supaya harum. Ada kepercayaan bahwa penggunaan kayu cempaka demikian akan membuat pemilik rumah selalu baikbaik dan disenangi tetangga.

e. Kayu Asem tidak boleh dipakai untuk bahan bangunan rumah karena akan membawa sifat yang tidak baik dalam hubungan antara pemilik rumah dengan tetangga.

f. Kemudian ada pula pantangan membuat atap rumah dengan bahan tanah karena tanah tempatnya di bawah. Jadi kalau ditempatkan di atas atap berarti si penghuni rumah tertutup atau terkubur tanah.

g. Selain itu ada kepercayaan pantang untuk menghuni rumah sebelum rumah yang dibangun dipasangi jendela dan pintu. Bahkan pemilik juga tidak boleh sekedar menginap apabila rumah masih dalam keadaan demikian.

\section{Beberapa Perubahan}

Seperti yang telah diindikasikan di muka dan dikhawatirkan oleh banyak pihak, arsitektur tradisional rumah Betawi memang sedang mengalami proses kepunahan. Keberadaannya tepat di tengah-tengah Kota Metropolitan Jakarta yang sedang berkembang dengan cepat nampaknya menjadi penyebab utama proses kepunahan ini.

Berikut, dicoba diuraikan beberapa indikasi yang menunjukkan perubahanperubahan yang terjadi terhadap keberadaan arsitektur rumah tradisional Betawi. Secara hipotesis dicoba diungkapkan faktor-faktor yang mempengaruhi terhadap keberadaan arsitektur rumah tradisional Betawi tersebut. Sebagai kasus, dipergunakan wilayah Condet, khususnya Kelurahan Balekambang untuk memperlihatkan perubahan-perubahan yang ada.

Perubahan dimaksud adalah akibat pengaruh lingkungan yang berarti terhadap keberadaan arsitektur tradisional rumah Betawi, baik secara kuantitatif maupun kualitatif. Hal ini terjadi di wilayah Condet Kelurahan Balekambang Jakarta Timur yang telah ditetapkan menjadi daerah Cagar Budaya.

Perubahan secara kuantitatif dimaksudkan sebagai perubahan lingkungan dengan dibangunnya rumahrumah baru yang bukan rumah tradisional yang akan merubah perbandingan rumah tradisional terhadap jumlah rumah yang 
ada. Kemudian perubahan secara kualitatif dimaksudkan sebagai perubahan-perubahan lingkungan seringkali mempengaruhi pengambilan keputusan untuk mengubah secara fisik rumah tradisional yang ada menjadi lebih modern. Artinya secara tidak langsung akan mengubah jumlah rumah tradisional yang ada.

Jika daerah Condet, Kelurahan Balekambang dijadikan daerah cagar budaya, maka diharapkan perubahan yang terjadi di daerah ini sedikit, namun dalam kenyataannya menunjukkan suatu perubahan yang cukup berarti. Dimungkinkan perubahan-perubahan yang terjadi tersebut, karena masuknya penduduk dari luar ke daerah ini. Peningkatan jumlah penduduk mengakibatkan peningkatan kebutuhan akan tempat tinggal. Hal tersebut akan mengubah suasana lingkungan permukiman tradisional dengan dibangunnya rumah-rumah baru yang bukan tradisional atau dimungkinkan karena alih generasi dan pindah tangan, sehingga dimungkinkan terjadi perubahanperubahan secara fisik terhadap keberadaan arsitektur tradisional rumah Betawi.

\section{Penutup}

Dari paparan di atas dapat disimpulkan bahwa arsitektur tradisional rumah Betawi adalah suatu fenomena yang tumbuh dari percampuran pengaruh berbagai kebudayaan, baik kebudayaan Indonesia maupun kebudayaan yang datang dari luar Indonesia. Di satu pihak, masyarakat Betawi itu sendiri merupakan masyarakat yang melahirkan hasil percampuran berbagai latar belakang budaya yang berbeda, baik karena banyaknya pendatang dari berbagai pelosok Indonesia maupun karena masuknya pendatang dari luar Indonesia ketika proses pembentukan arsitektur tradisional rumah Betawi ini banyak peristiwa penting di Jakarta dimulai sejak bernama Sunda Kelapa sampai bernama Jakarta yang melibatkan pelaku-pelaku dari berbagai tempat yang secara langsung maupun tidak langsung memperkenalkan unsur-unsur arsitektur asalnya ke Jakarta (Betawi).

Percampuran yang terjadi tersebut kemudian melahirkan arsitektur rumah tinggal yang beragam, baik dilihat dari jenis rumahnya maupun dilihat dari unsur-unsur arsitekturnya seperti struktur, tata ruang, dan ragam hiasnya. Paling tidak tiga jenis bentuk rumah yang ada di Betawi, rumah Joglo yang nampak secara langsung dipengaruhi oleh arsitektur tradisional rumah Jawa. Walaupun demikian, pengaruh ini tidak bulat. Rumah Joglo Betawi adalah tidak sama dengan rumah joglo di Jawa. Ini berarti di luar segi bentuk, ada ungkapanungkapan arsitektur lain yang merupakan hasil "penemuan" kebudayaan Betawi, yang khas dari arsitektur Betawi.

Rumah Bapang atau Kebaya dan rumah Gudang adalah dua variasi lain rumah tradisional Betawi yang menunjukkkan kekayaan arsitektur Betawi; belum termasuk variasi-variasi lain yang merupakan "penyimpangan" dari masing-masing ketiga bentuk atau variasi utamanya. Untuk kedua jenis bentuk arsitektur rumah ini, terlihat lebih jauh penemuan yang khas hanya terdapat pada arsitektur Betawi. Semisal pada arsitektur rumah tradisional Betawi, tidak dikenal konsep bagian "laki-laki" dan "perempuan" dari rumah begitu pula dengan bentuk rumah joglo yang biasanya justru terdapat pada arsitektur rumah Jawa maupun Sunda. Kemudian adanya penggunaan struktur kuda-kuda Eropa maupun Timur, serta adanya simetris. Walaupun apa yang disebutkan ini merupakan beberapa dari ciri khas arsitektur rumah tradisional Betawi, 
dapat dianalisa bahwa kedua jenis rumah ini mendapat pengaruh arsitektur rumah Jawa maupun Sunda serta pengaruhpengaruh budaya lain.

Kekhasan tetapi sekaligus keberagaman di dalam arsitektur rumah tradisional Betawi lebih terlihat dari ungkapan-ungkapan arsitektural yang lebih detail yang digunakan, seperti penggunaan bagian-bagian struktur dan konstruksi, penggunaan bahan, serta ragam hias; yang mengambil dari banyak pengaruh luar. Dua rumah dengan bentuk yang sama, semisal rumah Bapang atau Kebaya dijumpai masing-masing menggunakan suatu deatil konstruksi atau ragam hias yang berbeda.

Yang lebih menarik dari keberadaan arsitektur Betawi ini adalah kenyataan bahwa keragaman tersebut justru terdapat pada suatu wilayah yang relatif tidak begitu luas dan dari satu kebudayaan, yaitu kebudayaan Betawi bila dibandingkan dengan keragaman arsitektur Sunda karena memang ada pada wilayah yang cukup luas. Di sisi lain menunjukkan adanya berbagai pengaruh tadi yang berlangsung secara intensif dan keterbukaan masyarakat dan kebudayaan Betawi untuk menerimanya. Di lain pihak hal ini menunjukkan adanya suatu kekhasan tertentu dalam perwujudan khasanah arsitekturnya. Jika di daerah lain yang juga memiliki keragaman arsitekturnya, suatu ragam arsitektur di dalamnya biasanya lahir dari suatu sub-kebudayaan yang ada di daerah itu, sedangkan di Betawi, satu kebudayaan yaitu kebudayaan Betawi justru melahirkan sejumlah ragam arsitektur rumah tinggalnya.

Dengan demikian, jika kekhasan suatu arsitektur tradisional dari suatu kebudayaan adalah karena satu bentuknya yang khas, maka pada arsitektur rumah Betawi salah satu kekhasan karena keragamannya. Kekhasan lainnya adalah tentu saja karena apa yang ada pada arsitektur tradisional rumah Betawi, termasuk ungkapan-ungkapan arsitekturnya, tidak terdapat pada arsitektur tradisional lainnya (mutually exclusive), walaupun arsitektur Betawi lahir dari suatu proses percampuran budaya.

\section{DAFTAR PUSTAKA}

Alamsyah P., Suwardi et al. 2007. Arsitektur Bangunan Tradisional Masyarakat Baduy Panamping. Laporan Penelitian. Edisi 38/ September 2007. Bandung: Depbudpar. Balai Pelestarian Sejarah dan Nilai Tradisional.

Fajria R., Heni dan Toto Sucipto. 2000. Kampung Adat dan Rumah Adat di Jawa Barat. Bandung: Disbudpar Provinsi Jawa Barat.

Garna, Judistira. 1984.

'Pola Kampung dan Desa; Bentuk serta Organisasi Rumah Masyarakat Sunda" dalam Ekajati, Edi S. (ed). Masyarakat Sunda dan Kebudayaannya. Bandung: Girimukti Pusaka.

Haryoso. 1982.

"Masyarakat Sunda" dalam Koentjaraningrat (ed.). Manusia dan Kebudayaan di Indonesia. Jakarta: Djambatan.

Prosiding Seminar. 2004.

Pengembangan Kawasan Tertinggal Berbasis Komunitas Adat Terpencil. Bapenas.

Saidi, Ridwan. 2000.

Siklus Betawi: Upacara dan Adat Istiadat. Jakarta: Lembaga Kebudayaan Betawi (LKB) bekerjasama dengan Dinas Kebudayaan Provinsi DKI Jakarta.

Suhamihardja, A. Suhandi dan Yugo Sariyun. 1991. 
Kesenian Arsitektur Rumah dan Upacara Adat Kampung Naga Jawa Barat. Jakarta: Depdikbud. Ditjen Kebudayaan. Proyek Pembinaan Media Kebudayaan.

Surakhmad, Winarno.1985.

Penelitian Dasar Metode Teknis. Bandung: Tarsito.

Tim Koordinasi Siaran. Dirjen Kebudayaan. 1992/1993.
Aneka Ragam Khasanah Budaya Nusantara. Jilid IV. Jakarta: Depdikbud. Dirjen Kebudayaan. Proyek Pengembangan Media Kebudayaan.

2006.

Pengkajian Filosofis Arsitektur Betawi. Jakarta: Dinas Kebudayaan dan Permuseuman. Pemerintah Provinsi Daerah Khusus Ibukota Jakarta. 